\title{
Intralesional Triamcinolone Regimen
}

National Cancer Institute

\section{Source}

National Cancer Institute. Intralesional Triamcinolone Regimen. NCI Thesaurus. Code C160064.

A chemotherapy regimen consisting of intralesional triamcinolone that may be used in the treatment of primary cutaneous B-cell lymphomas. 